\title{
A szociális munkás szerepe a felnőtt értelmi fogyatékossággal élő személyek párkapcsolatainak segítésében
}

\author{
The role of social workers in supporting adults with intellectual \\ disabilities with intimate relationships and sex
}

FARKAS ANETT \& JÁVOR REBEKA

Farkas Anett: BA-hallgató; Pécsi Tudományegyetem, Bölcsészet- és Társadalomtudományi Kar, Társadalmi Kapcsolatok Intézete, Közösségi és Szociális Tanulmányok Tanszék; controlanett@gmail.com

Anett Farkas: BA student; University of Pécs, Faculty of Humanities and Social Sciences, Institute of Social Relations, Department of Community and Social Studies; controlanett@gmail.com

Jávor Rebeka: Pécsi Tudományegyetem, Bölcsészet- és Társadalomtudományi Kar, Társadalmi Kapcsolatok Intézete, Közösségi és Szociális Tanulmányok Tanszék; javor.rebeka@pte.hu

Rebeka Jávor: University of Pécs, Faculty of Humanities and Social Sciences, Institute of Social Relations, Department of Community and Social Studies; javor.rebeka@pte.hu

\begin{abstract}
Absztrakt
Az emberek többsége úgy gondolja, hogy a fogyatékkal élőknek nincs szükségük kapcsolatra, szerelemre, érintésre, és hogy nem is képesek rá. Rengeteg tévhit kering róluk ezzel kapcsolatban, mégis kevéssé kutatott a terület, csekély szakirodalom áll rendelkezésünkre. Fontos kérdés, hogy az értelmi fogyatékkal élőknél hogyan zajlik az ismerkedés, és a család, környezet miként tud ebben segíteni. Milyen lehetőségeik vannak a párkeresésre: helyszín, társkereső oldalak, csoportok stb.? Milyen egy ilyen párkapcsolat, együtt élnek-e, ha nem, milyen sürün találkoznak? Mit gondolnak a nemi életről és honnan szereznek/szereztek ismereteket róla? Hogyan, miben tud a szociális segítỏ segíteni?
\end{abstract}

Kulcsszavak: értelmi fogyatékosság, szexualitás, párkapcsolatok, szociálismunkás-szerep

\begin{abstract}
It is widely believed that people with disabilities do not need relationships, love, touch and are unable to do so. There are many misconceptions about this group, yet little research has been conducted on these phenomena. Relevant questions are how dating with a person with intellectual disability takes place and how the family and the environment can help in this process. What options do they have for dating: location, dating sites, groups, etc.? What is such a relationship like, do they live together, if not, how often do they meet? What do they imagine about sex and where do they gain answers about it? How can a social worker help?
\end{abstract}

Keywords: intellectual disability, sexuality, relationships, social worker's role 
Farkas A. \& Jávor R.: A szociális munkás szerepe a felnőtt értelmi fogyatékossággal élő személyek...

\section{A fogyatékosság definiálása}

A fogyatékosság biológiai terminusokban gyökerezik, ám társadalmilag konstruált testi és értelmi állapot. A szociológiai megközelítés abból indul ki, hogy a fogyatékosságok társadalmilag határolódnak el, vagyis a fogyatékosság nem tisztán tény, hanem a társadalmi értékelésből eredő viszony és érték (Bánfalvy, 2003).

A fogyatékosságot a normálistól való eltérésként is szokták/szoktuk emlegetni, de az, hogy mit tartanak/tartunk normálisnak és abnormálisnak, függ azoktól az egyénektől, csoportoktól, akiktől a meghatározás származik. Különböző fizikai, társadalmi, gazdasági és földrajzi körülmények e meghatározásokat befolyásolni tudják (Bánfalvy, 2000). Beszélhetünk evidens fogyatékosságról, mely egyértelmüen diagnosztizálható, nem összetéveszthető és nem elrejthető, valamint nem evidens fogyatékosságról. Másfelöl a szokásostól való eltérés sem egyértelmüen fogyatékosságként értelmeződik, hiszen pl. a szemüvegességet nem mindig tekintik a modern társadalomban fogyatékosságnak (Bánfalvy, 2003). Az Egészségügyi Világszervezet fogyatékosságmeghatározása szerint a fogyatékosság nem zárja ki az egészséget, nem betegség, hanem állapot (Forrai, 2020).

Gyógypedagógiai szempontból fogyatékossággal élőnek nevezzük azokat az egyéneket, akikre jellemző, hogy biológiai, pszichológiai, szociális tényező következtében idegrendszerük, vagy valamely érzékszervük perifériás része organikusan vagy funkcionálisan sérült, fejlődésük menete, személyiségszerkezetük eltér az egészséges emberektől; személyiségfejlesztésük gyógypedagógiai eszközöket igényel. A megváltozott fejlődésmenet következtében bizonyos funkciók nem alakulnak ki, vagy módosulnak, megváltozik az információfelvétel, nehézzé válik a társadalmi kommunikáció, a szocializáció, ennek következtében izoláltság következhet be. A tudomány a különféle fogyatékossági csoportokon belül osztályozási szempontokat is számontart, mint pl. a súlyossági fok, időfaktor, intelligenciaszint, szocializálhatóság stb. (Cs. Horváth, 1987).

Fontos tényező azonban az, hogy bizonyos értelemben, az ember normális vagy abnormális voltának megítélése pusztán biológiai szempontból nem helyes, mert nem felel meg a „humán-tudományos” emberszemléletnek: ha az ember biológiai értelemben abnormális volta ellenére be tud illeszkedni a társadalomba, sőt sok esetben önálló életvezetésre is képes, akkor abnormálisnak ítélhetjük-e meg (G. Szabó, 1996)?

Mint ahogy a gyermekkorról alkotott kép is formálódik a korszakok és kultúrák váltakozásával, úgy az értelmi fogyatékosság képe is. Az értelmi fogyatékossággal élő gyermekekről és felnőttekről alkotott képet egy olyan, szociális közegben létrejövő heterogén szerkezetü mentális konstrukcióként értelmezzük, amelyben az adott korszakban és kultúrában az értelmileg akadályozott gyermekekről és felnőttekről alkotott gondolatok, vélekedések, teóriák, koncepciók, elöítéletek és más narratívumok öltenek testet (Magyar, 2018). „Az értelmi fogyatékosság meghatározása és az értelmi fogyatékossággal élö emberek jellemzése során egyoldalúan a megkülönböztetések, a hiányok szerepelnek. Mi az, ami ö nem, mi hiányzik belöle, mit nem tud. Ennek következtében a kultúrában a velük való bánásmódot évszázadokon keresztül a kirekesztés, elszigetelés jellemezte” (Zolnai, 2001, p. 13).

A fogyatékossággal élő emberek helyzete az ezredfordulót követően jelentős változásnak indult. Ez elsősorban az európai tendenciák hazai szintü megjelenésének köszönhető, másfelől az érintettek társadalmi integrálódása is erőteljesebbé vált, valamint különböző szintü szakmapolitikai kezdeményezések is elindultak. Magyarországon a 20. század végéig a fogyatékossággal élő emberek ügye nem vált közüggyé, a család problémája maradt. A 21. században pozitív változás figyelhető meg, mely azt jelenti, hogy az érintett 
csoport helyzete és társadalmi élettere folyamatosan átalakul, az integráció előtérbe került (Laki, 2013). Ez már csak azért is fontos, mert az utolsó, 2016-os adatok alapján, akkor Magyarországon a fogyatékossággal élők 13,14\%-a volt értelmi fogyatékos, ami 53603 főt jelentett (KSH, 2021) (kurrensebb adatok nem állnak rendelkezésre).

\section{Mit tekintünk romantikus kapcsolatnak? Mi a szerelem?}

Az, hogy kinek mit jelent a szerelem, egyénenként változik, hiszen mindenki máshogy fejezi ki az érzelmeit. Akár egy ép, akár egy fogyatékossággal élő egyént kérdezünk meg arról, hogy mi a szerelem, először nehézséget okoz mindkettőjüknek ezt szavakba önteni.

A szerelemben az összes érzelem benne van, a szorongástól és kétségbeeséstől kezdve az örömig. Az, hogy hogyan érzékeljük a szerelmet, azon múlik, hogy az előző generáció milyen szabályokat, mintákat, rítusokat mutat(ott), ad(ott) nekünk. A szerelem egy olyan hatalom, amely összeköti az embereket egymással és biztonságérzetet ad. A szerelem szeretetet, érzelmeket, cselekedeteket, tudást és készségeket tartalmaz, de az egyedisége és a tapasztalatokon alapuló jellege miatt nem lehet túl szigorúan értelmezni (Mattila et al., 2017). A romantikus kapcsolatokat nagyban befolyásolja a kötődés, mely az ember életében már csecsemőkorban kialakul édesanyja, ill. az elsődleges gondozó felé, így a kötődés olyan viselkedéses rendszer, amely a kötődési személyhez való közelség elérését célozza meg.

Bowlby (1969, 1973, 1980) feltételezte, hogy a kötődés három funkciója - a közelség keresése az elsődleges gondozóval stresszhelyzetben, a biztonságos menedék, ahova mindig vissza lehet térni támaszért, és a biztonságos bázis, ahonnan a világ felfedezése és az autonómia bontakozása indulhat - a felnőttkori partnerkapcsolatokban is alapvetően jelen van. Meggyőződése volt, hogy az elsődleges gondozóval kialakult kötődés minősége meghatározó szerepet játszik felnőttkorban az érzelmi kapcsolatok létrejöttében, fenntartásában és azok egyéni mintázatának alakításában (Hámori, 2014).

A korai időszak eseményei különös jelentőséggel bírnak eltérő fejlődésű gyermekek esetében. Az anya a korai időszakban a nagyfokú pszichés leterheltsége miatt kevésbé lehet nyitott a gyermek másféle, egyébként is nehezen olvasható jelzéseire, így akár sérülhet a kölcsönösség, és negatív interakciós körök alakulhatnak ki. Az anya kevesebb visszajelzést kap, ami növeli bizonytalanságát, és a gyermek kisebb örömforrást jelent. Ez mellett egy másik fontos mozzanat, mely befolyásolja a kölcsönösség alakulását, a szülő kognitív szüröje, melyen keresztül gyermeke viselkedését látja. Az atipikus fejlődés számos olyan fejlődési jellegzetességet és korai viselkedésbeli eltérést indukál, amely releváns lehet az anya-gyerek kapcsolat alakulásában (Mándoki, 2018).

\section{Mit gondolnak a fogyatékossággal élők a szerelemről?}

Egy 2017-es tanulmányban hét enyhe értelmi fogyatékossággal élő személyt kérdeztek arról, hogy mi a szerelem. Öt nő és kettő férfi vett részt a vizsgálatban, életkoruk 18 és 31 év között mozgott. Fontos szempont volt a mintaválasztásnál, hogy mindegyik személy képes legyen kifejezni véleményét és érzelmeit szavakban. Az enyhe értelmi fogyatékossággal élő fiatalok képességeikhez mérten őszintén és nyíltan válaszoltak.

Szerintük fontos, hogy a partnerük szép vagy jóképű legyen. Bár nem ez az egyetlen szempont, ez mellett sokan megemlítették a közös érdeklődési kört, amely lehetővé teszi, hogy közösen tudják a szabadidejüket eltölteni. A kutatásban részt vevő fiataloknak hasonlóak a 
Farkas A. \& Jávor R.: A szociális munkás szerepe a felnőtt értelmi fogyatékossággal élő személyek...

jövőbeli elképzeléseik, melyeket szeretnének megosztani egy partnerrel. Ezen kívül említésre került még az intimitás, és az, hogy az álompartner legyen romantikus és kedves. Mindegyik fiatal pozitív és jó érzésnek tartotta a szerelmet, negatív érzéseket nem társítottak hozzá. A többség szerint ez egy személyes érzés, és néhányan azt is megemlítették, hogy szerelembe esni fizikai változásokkal jár. Azt vették észre, hogy amikor a szerelmük a közelben van, az fizikai reakciókat vált ki belőlük, pl. kipirulnak és a gyorsabban kezd verni a szívük (Mattila et al., 2017).

Az értelmi fogyatékossággal élők is hasonló érzelmeket és szempontokat említenek meg a szerelemmel kapcsolatban, hasonló jellegü kapcsolatra vágynak, mint ép társaik.

\section{Szexualitás}

A szexualitás funkciói közé tartozik alapvetően a reprodukció, de ezen kívül az örömszerzés, a szeretetképesség, a stresszoldás, a szocializációs folyamat elősegítése, a kommunikáció javítása és a személyiségfejlesztés is (Forrai, 2020). Nemi ösztönökkel születik mindenki, de ezeket „ember módjára” megélni csak tanulás útján lehet.

A mai, 2020-as évek nézőpontjai szerint, a közösség gyakran gyermek- vagy betegszerepbe kényszeríti a fogyatékossággal élő személyeket, csökkent önállóságukból és felelősségvállalási képességükből kiindulva. Mindez sajátos következményekkel jár a szexuális viselkedésük megítélésében, hiszen a társadalom a „,beteg” embertől és a gyermektől megvonja az önállóság, az autonómia és így a szexualitás jogát is. Zolnai (2001) saját tapasztalatát osztja meg munkájában, mely szerint egy gyermek- és felnőttkorú fogyatékossággal élőket ellátó intézményben a fiatal gondozónőkben fel sem merült, hogy a rövid köpeny vagy a miniszoknya a férfi gondozottak körében szexuális kihívást jelenthet. Számukra ők nem potenciális férfiak, hanem örök, ártatlan gyerekek. A gyermek- és a betegszerep is alapvetően aszexuális, így a társadalom a fogyatékossággal élőkre is így tekint - ezt mutatja pl. az akadálymentesített mosdók kialakítása is, amelyek koedukáltak, nincs külön női vagy férfi akadálymentesített mellékhelyiség. Egyes nézőpontok szerint a nemtelenség megkönnyíti a gondozási feladatokat a környezet számára, és a fogyatékossággal élöket megóvhatja a csalódásoktól, a nemiségből adódó problémáktól (Zechmeister, 2016).

Amellett, hogy a társadalom aszexuális „lényként” tekint a fogyatékossággal élőkre, számos tévhit is kering a szexualitásukról. Ezekből Forrai Judittól (2020) idézünk néhányat:

- a fogyatékossággal élő nőknek és férfiaknak nem kell a szex,

- a fogyatékossággal élő nők és férfiak nem érezhetnek szerelmet,

- minden fogyatékossággal élő ember heteroszexuális,

- a fogyatékossággal élő nőknek és férfiaknak nem kell gyerek, és nem szabad megengedni, hogy gyermeket vállaljanak.

A szexualitásra vonatkozóan meglehetősen szerteágazó véleményekkel találkozhatunk, ezért nem egyszerü a fogyatékossággal élő emberrel szemben elfogadó és ítélkezésmentes magatartást tanúsítani. A szülők, orvosok, pedagógusok, szociális segítők és az egész társadalom felelőssége, hogy adott lehetőségek között és ésszerü kötöttségek mellett megoldás szülessen e téren. Az intézményeknek állást kell foglalniuk a párkapcsolatok, a nemiség kérdéseinek mindennapi kezelésében. Egyértelmü döntést kell hozniuk, hogy támogatják-e a párkapcsolatokat, szexuális kapcsolatokat vagy sem, és hogy tudnak-e ehhez megfelelő teret 
biztosítani. Ha támogatják, akkor szükség van konkrét célok és szabályok megfogalmazására, mellyel minden fél tisztában van, melynek következtében csökken a segítök egyéni felelössége, és egy komplex értékrend alakul ki az intézményben (Zolnai, 2001). Forrai Judit (2020) véleménye szerint magáról a szexualitásról szóló mindennapi beszélgetéseink során, az aktuális problémák megoldására irányuló segítségkérés, segítségnyújtás, oktatás, felvilágosítás területén még mindig a szemérem és szégyen határán állunk, annak ellenére, hogy általában komoly erőfeszítéseket tettünk és teszünk szexualitásunk megértése és a megfelelő társadalmi diskurzus érdekében - ugyanakkor a fogyatékossággal élők szexualitása terén még ezekben is különösen keveset teszünk.

Az értelmi fogyatékossággal élők önállóságának érvényesülését még mindig számtalan akadály nehezíti. Az intézményekben szigorú napirend és szabályrendszer szerint élnek a lakók, nem rendelkeznek saját privát térrel, és az egyéni szükségletekre való odafigyelés lehetősége erősen korlátozott. Bár a magánéletre kevés az esély, hosszabb vagy rövidebb párkapcsolatok mégis kialakulnak, amely megoldandó kérdés elé állítja az intézményt. Magyarországon több intézmény fenntart egy ún. intimszobát, ahol a párok ugyan nyitott keretek között, de privát térrel és idővel rendelkezhetnek. Bár ez már haladó lépésnek tekinthető, emberi jogi szempontból továbbra is elfogadhatatlan megoldás: az intimszoba kialakításának gyakorlata ellentmondásban áll az emberi méltóság és a magánélethez való jog követelményével (Balogh et al., 2016). Van intézmény, ahol a szexuális életet szigorú szabályok akadályozzák meg, vagy akár nyugtatókat alkalmaznak e célból. Magyarországon alig van otthon vagy intézmény, ahol együtt élhetnének a párok. A lakók és a segítő személyzet többnyire problémaként éli meg a szexualitás jelenlétét (Forrai, 2020).

\section{A szexuális nevelés típusai}

A szexuális nevelés típusát az egyén nemiséggel kapcsolatos beállítottsága határozza meg, amely lehet pozitív, negatív vagy semleges. A nemiséghez pozitívan viszonyuló egyén a fejlesztő-segítő (progresszív) nevelést választja, mely fejleszteni, támogatni kívánja az egyén szexuális életét mint testi-lelki egészségének fontos tényezőjét.

Az értelmi fogyatékossággal élő emberek szexuális viselkedéséből sok esetben hiányoznak a szocializációs alapok, ezért úgy tünhet, hogy szexuálisan deviánsak. A fizikai ellátásuk mellől gyakran hiányzik a tanítási folyamat, melyet mások a családban vagy az iskolában kapnak meg. Kevésbé esik erről szó az intézményekben, jellemzően nem foglalkoznak ezzel a témával. Ezért hatványozottan fontos az értelmi fogyatékossággal élő emberek integrációja és felkészitése, amely lehetőséget biztosít(ana) a személyes kapcsolatok fejlesztésére, ennek viszont esszenciális része a párkapcsolatok elismerése a család, az intézmények és a társadalom részéről, az intimitásról való beszélgetés lehetősége, segítése, a szexuális nevelés (Forrai, 2020).

\section{Minta és módszerek}

A kutatás célja az értelmi fogyatékossággal élők ismerkedési szokásainak feltérképezése, párkapcsolataik megismerése, ill. a segítők tapasztalatainak és véleményeinek feltárása annak érdekében, hogy képet kapjunk arról, hogy egy értelmi fogyatékossággal élőket ellátó alapítványnál mennyire foglalkoznak a párkapcsolat és a szexualitás témakörével, továbbá, hogyan és milyen módszerekkel támogatják a kliensek párkapcsolatait az ott dolgozó segítők. 
Farkas A. \& Jávor R.: A szociális munkás szerepe a felnőtt értelmi fogyatékossággal élő személyek...

A kutatás módszereként kvalitatív megközelítésre esett a választás. Tematikus kvalitatív interjúk készültek hat értelmi fogyatékossággal élő nővel (a megkeresett férfi kliensek nem vállalták a részvételt) és egy szociális segítővel (Zs). Az interjúalanyok enyhe és középsúlyos értelmi fogyatékossággal élő személyek, akik közül hárman támogatott lakhatásban ( $\mathrm{Tl})$ laknak, ketten a szüleikkel és egy pedig lakóotthonban, viszont mindegyikük egy nappali ellátást nyújtó intézmény tagjai. Életkoruk 25-48 év közé tehető.

A kliensek interjúi 131 és 393 szó közöttiek, míg a segítővel készített interjú 1364 szóból áll. Az interjúkérdések összeállításakor fontos szempont volt, hogy a kérdések egyszerüek és könnyen értelmezhetőek legyenek, valamint ne legyenek sugalmazók, ill. befolyásolók.

A tematikus kvalitatív interjú olyan félig strukturált beszélgetés, amely a mindennapi élet egy szegmensét igyekszik körüljárni. A kliensek így elmesélték a párjukkal való megismerkedésüket és néhány ehhez szorosan kapcsolódó történetet is. A cél ezzel a módszerrel az, hogy megismerhessük az egyén tapasztalatait, megélt élményeit és érzéseit a saját szempontjából, nem pedig a tények, narratívák feltárása (Kvale, 1996), de a beszélgetés mindig egy behatárolt téma körül forog, ami e kutatás során a párkapcsolatok minősége és fejlődése. A félig strukturált jelleg pedig abban nyilvánul meg, hogy az interjúvezető vegyíti a nyitott és a behatárolt kérdéseket, valamint teret enged a válaszadó által feltett szempontoknak is. Rugalmas, de ugyanakkor mindig szem előtt tartja a saját kutatási kérdését is (Szokolszky, 2004).

Az interjúk nyugodt, biztonságos közeget és helyszít igényelnek (különösként a vizsgált csoportban), így egy nyári tábor alkalmával, a lakószobákban, egyéni keretben zajlottak. A résztvevők az interjú előtt tájékoztatást kaptak az anonimitás biztosításáról, továbbá arról, hogy milyen céllal készülnek az interjúk. A megkérdezettek önként döntöttek arról, hogy név nélkül vállalják az interjún való részvételt, és beleegyezésüket adták arra is, hogy rögzítésre kerüljön a beszélgetés.

Messzemenő általánosításokat ugyan nem vonhatunk le a tanulmányból, nem is cél az ilyen általánosítás, de betekintést nyerhetünk abba, hogy egy speciális jelenség miként nyilvánul meg a „mindennapokban”.

\section{Az elemzés eredményei}

Az interjúkat a kérdésekben megfogalmazott, valamit a spontán felbukkanó témáknak megfelelően elemeztük. Ezek a témák a következők voltak: párkapcsolatok kialakítása, azok minősége, szexuális felvilágosítás és szexuális magatartás. A tematikus elemzés eredményeit az alábbiakban a Fogd a Kezem Alapítványnál zajlott résztvevő megfigyelések eredményeivel integrálva közöljük.

A Fogd a Kezem Alapítványnál töltött napok tapasztalatai szerint a legtöbb kliensnek volt már párkapcsolata. Ezek a kapcsolatok ,alapítványon belüliek”, ám többségük nem komoly románc. Az értelmi fogyatékossággal élő személyek vágynak a szerelemre, szeretetre, korosztálytól függetlenül. Gyakran féltékenyek is azokra a társaikra, akik boldog kapcsolatban élnek.

ZS: Sok fiatalon (kliensen) látom, hogy nincs levezetve ez az energia, sok esetben, akik kevésbé súlyosak ebből a szempontból, sajnálom őket. Ott van ez az alapszükségletük de nem tudják kielégíteni. Nagyon megoldatlan ez a dolog, és nagyon prűd nemzet vagyunk mi ahhoz, hogy egyáltalán beszéljünk erről a problémáról. 
Előfordul, hogy a kliens segítséget kér az egyik segítőtől, mivel neki tetszik valaki, és tanácstalan, hogyan tudna közeledni a választottjához. Tehát ebböl a szempontból egyfajta bizalmi kapcsolat alakult ki a segítő és a kliens között, melynek segítségével már több párkapcsolat is létrejött.

Az enyhe értelmi fogyatékossággal élőkre jellemzőbbek a hosszútávú, mély érzésű komoly kapcsolatok, amelyekben mint nö és férfi kiteljesedhetnek. A középsúlyos értelmi fogyatékossággal élők is ugyanúgy vágynak a kapcsolatra, ám ezek általában rövidebb ideig tartanak és inkább baráti jellegüek. Tehát, úgy tünik, a fogyatékosság mértéke nagyban befolyásolja a kapcsolatok milyenségét és minőségét, továbbá azt, hogy a fogyatékossággal élők mennyire tudnak mély szerelmi érzelmeket táplálni valaki iránt.

\section{FA: Volt már párkapcsolatod? Hogy ismerkedtetek meg?}

$\mathrm{K}$ : Volt is már meg van is. Most a TT-vel 3 hónapja vagyunk együtt, jól megvagyunk, és nagyon szeretem. Szeretek kapcsolatban lenni. [...] A napköziben odajött hozzám, és megtetszettünk egymásnak. TT a lakóotthonban lakik és ott voltam már nála kétszer is.

D: Igen, a T-vel járok már nagyon hosszú ideje. A napköziben volt, hogy egyszerre négy fiú udvarolt, én pedig mondtam, hogy egy kis időt szeretnék kérni, hogy gondolkozzam. Köztük volt a T is, és a fiúktól sok bókokat kaptam. Elkezdtem otthon gondolkozni, aztán lecsökkentettem a számot kettőre, mert rájöttem, hogy a másik két fiút csak a külsőség érdekli, és ők nagyon felvágósak voltak, hogy a szüleik milyen gazdagok, ez meg nekem pont nem jött be. Aztán a harmadikat is elküldtem, mert ő meg nagyon tapadós volt, és állandóan csak velem akart lenni, a végén pedig bevallotta, hogy ő már mással szemezget, ami pedig rosszul esett nekem. T-t választottam, ö az én igazi párom. Szülinapi ünnepségen kérdezte meg, hogy tudtam-e gondolkozni rajta, és mondtam, hogy igen, nekem ő tetszik, és ő is ezt mondta, és azóta vagyunk együtt. Már tíz éve együtt vagyunk, de még mindig sokat szoktunk bókolni egymásnak.

P: Van, négy éve a P. A napköziben ismerkedtünk meg, megkért, hogy legyek a barátnője, és azóta már a kezem is megkérte.

O: Volt is meg van is, a D. A napköziben. Miután a B szakított velem, nagyon sokáig depressziós voltam, meg ki is voltam borulva, sokat sírtam is, és kis híján kárt tettem magamban. Aztán jött a $\mathrm{D}$, és már minden rendben.

É: Igen, van, a B már egy jó ideje. Ott dolgozik ő is a napköziben, és ott ismerkedtünk meg. Nekem nagyon tetszett, sokat néztük egymást, meg mindig odamentem hozzá.

E: Volt már, igen, nem is egy. Sok munkahelyem volt, mert változtattam, és így több volt. Általában a napköziben. Rossz, mert a Tl-be nem szabad felvinni fiút, ezért nem is nagyon szeretnék most, hogy nem alhatunk együtt. Jó lenne olyat találni, aki mellett tudok fejlődni.

Előfordul azonban az is, hogy alkalmanként meglátogatják egymást otthonaikban, a szülők tudtával és felügyelete mellett.

P: Voltam már náluk, csókolózni szoktunk, enyelegni.

É: [...] egyszer voltam náluk, az nagyon jó volt. Ö még nem volt nálunk, de már meghívtuk, viszont a Tl-ben volt már, mert segített festeni.

E: Volt, hogy elmentünk kirándulni vagy anyuméknál voltunk.

A lakóotthonban fogadhatnak vendégeket az ott élök, viszont a lányok/nők támogatott lakhatásukba fiú/férfi vendéget nem vihetnek fel magukkal, amit sérelmeznek is. 
Farkas A. \& Jávor R.: A szociális munkás szerepe a felnőtt értelmi fogyatékossággal élő személyek...

A szülök (általában) támogatják gyermekeiket és örülnek, ha hosszabb ideje élnek gyermekeik monogám párkapcsolatban, amire akár még építeni is lehet. Sajnos volt már olyan, hogy azért nem támogatott egy szülő egy kapcsolatot, mert a gyermeke mellé ép társat képzelt el, azonban ez elég ritkán valósul meg.

\section{FA: A szüleitek támogatják a kapcsolatotokat?}

O: Persze, anyáék is elfogadták. Először anyukám jött azzal a kérdéssel, hogy ugye ő nem agresszív, de mondtam neki, hogy ő nem az, tök normális, értelmes ember. Amikor volt a szülőparti, akkor ott volt anyukám, bár D anyukája sajnos nem volt ott. Anyukám meg apukám tudott ott beszélgetni a D-vel.

E: Az anyukája nem fogadott el engem, a többi családtagja igen. Az én családomnak sem volt szimpatikus, az én családom nem szeretné, ha sérült lenne a párom. Olyat szeretnének mellém, aki engem még felemel, fejlődni tudok mellette.

Az iskolai egészségnevelési és szexuális nevelési foglalkozások ma már az általános és középiskolák döntő többségében jelen vannak. Kisebbségben vannak azok az iskolák, ahol ezek tantervbe beépítve heti rendszerességgel történnek, inkább az a jellemző, hogy osztályfőnöki órán évente néhány alkalommal foglalkoznak a témával a pedagógusok vagy egészségnevelök (Fábián \& Simich, 2006).

Az értelmi fogyatékossággal élők intézményeiben is nagy szükség lenne arra, hogy az ilyen foglalkozások ne csak néhány alkalommal valósuljanak meg. Nekik nagyobb szükségük van az ismétlésekre ahhoz, hogy el tudják sajátítani a tanultakat. Ugyanakkor az egészségnevelés tematikája mellé fontos lenne beépíteni olyan anyagot is a fejlesztésbe, mint a párkapcsolati etika, mellyel elkerülhető lehetne számos kellemetlenség, mint pl. az erőszakosság, illetlenség és túlzott elvárások. A pécsi Fogd a Kezem alapítványnál egy ún. Ámor-klubot tartanak külön a fiúknak és a lányoknak, ahol olyan témákról beszélnek, mint a testrészek elhelyezkedése és funkciói, szexuális nevelés és etikett. Kezdetben a fiúknak tartottak felvilágosító foglalkozást, majd a lányok is jelezték, hogy szeretnének ők is maguknak Ámor-klubot. Az alaptematika a szexuális felvilágosítás lett volna, de időközben kiderült, hogy a klienseknek komoly gondot jelent a belső testrészek elképzelése és elhelyezése.

Az Ámor első pár foglalkozása azzal telik, hogy egy 3D-s ábrát levetkőztetnek egészen a csontozatig, és ez alapján átbeszélik a testrészeket. Körülbelül fél évente indul újra az Ámorklub, mert az ismereteket többször át kell beszélni, nehezen épülnek be ezek az új információk. A lány Ámor három részből tevődik össze: az emberi testrészek elhelyezkedése és funkciói, a szexuális kapcsolatok és a férfi-női illemszabályok:

- Mik azok a tettek, amiket a lányoknak vagy fiúknak már nem szabad tolerálni, amikor már segítséget kell kérni egy felnőttől. Gondolunk itt fizikai bántalmazásra, szexuális erőszakra, érzelmi kihasználásra, túlzott féltékenységre stb.

- A kliensek gyakran filmek és mesék alapján képzelik el a kapcsolatokat, randevút, ezért sokszor olyan téveszmékben élnek, mint hogy a fiúnak kell állnia a randevú költségeit, el kell halmozni a lányt ajándékokkal. A lányok gyakran ezt ki is használják, és kérnek a fiúktól édességeket, ékszereket, ruhákat - de akkor felmerül a kérdés, hogy mivel kell ezt a lánynak kompenzálnia? 
ZS: Sok fiú nézi a pornófilmeket, amikben durva dolgok is vannak, és volt, hogy megcsinálta a barátnőjével, ami persze nem tetszett neki, a fiú pedig nem értette, hogy miért. Szóval a fiúkat is nagyon fel kell készíteni az ilyenekre, hogy mit lehet, mit nem. Nincs rossz szándék a fiúkban, csak nem tudják ezeket, és ezekből a filmekből indulnak ki.

D: A gyerekekről [szoktak beszélgetni az Ámoron], meg hogyha a fiú meghív valahova, akkor mit illik és mit nem. Ha nem szeretnének babát, akkor hogyan kell védekezni. Én ezt így megértettem, mert anyukámmal többször beszéltünk már erről. Sokszor álmodozom arról, hogy mi lenne, ha gyerekünk lenne, de nekem nem is lehetne a gyógyszerek miatt. [...] de nekem volt egy rossz élményem. Általános iskolában rám mászott egy fiú egy táborban, és nem engedett el. Hiába próbáltam a szorításából engedni, és szólni egy nevelőnek, nem bírtam. És ez egy játék keretében derült ki, mikor én elmondtam a nevelöknek, és nagyon megdöbbentek. Tapogatott, csúszkált rajtam, mint aki babát szeretne tőlem. Szülői értekezletet szerveztek, ahol azzal vádoltak engem, hogy én hagytam magam, pedig ez nem igaz. Azóta, ha erről beszélek, összeszorul a gyomrom, de úgy gondolom, hogy az az élet rendje, hogy elmondjuk a nehézségeinket.

O: [...] régen, mikor lehetett lakós-lakóssal együtt járni, akkor a $\mathrm{P}$ akart tőlem szexet, csak én nem engedtem neki. A D-vel várunk még ezzel.

A szexualitásról és védekezésről először gyakran a szüleik mesélnek a klienseknek, de előfordul olyan is, aki azon a véleményen van, hogy az ő gyermekének erről nem kell tudnia, és ezért megtiltja azt is, hogy részt vegyen ezen a foglalkozáson. Sokszor kevés az, hogy az intézmény oldaláról megvan a kellö igyekezet a szexedukációra, ha a szülő nem partner ebben.

A családokban többnyire tabutéma a szexualitás, és sok gyermek az iskolából vagy egyéb helyről szerez tudomást a témával kapcsolatban. Az egészség szempontjából is fontos lenne, hogy kellő felvilágosítást, tájékoztatást kapjanak, hiszen így, az ismeretek hiányában, jóval több rizikónak vannak kitéve a nemi betegségek, a nem kívánt terhesség, ill. a szexuális kiszolgáltatottság tekintetében (Zechmeister, 2016).

ZS: Van olyan fiatal, aki teljes mértékig tisztában van a dolgokkal, viszont van olyan szülö, aki teljes mértékig elutasítja, hogy az ő gyermeke ilyenröl tudomást szerezzen. Ez szerintem borzalmas, mert egyáltalán nem tudja, hogy mire való a nemi szerve. [...] Nagyon sok fiatalnál előjön, hogy nem tudja kiélni ezeket a szükségleteit, és ebből egy baromi nagy feszültség árad belölük. Az is megdöbbentő számomra, hogy nem csak nem csinálhatja, hanem nem is beszélhet róla.

ZS: Van olyan szülö, aki nagyon szereti, hogy van párkapcsolata a gyermekének, viszont ne jusson el szexuális együttlétig a dolog. Olyan is van, aki megengedi azt is, viszont kéri, hogy a fogamzásgátlást meg én próbáljam neki elmagyarázni, mert ő nem tudja, hogy kell.

ZS: [...] van egy fiatal, akinek már gyereke is van. Ök jártak úgy, hogy gyereket szerettek volna, és elmentek egy genetikai vizsgálatra, hogy az ő betegsége öröklődik-e, és mondták neki, hogy 50-50\% esély van rá, hogy igen. Jött oda hozzám, hogy neki megállapították ezt a szindrómát, és azt mondta az orvos, hogy ez egy kromoszómabetegség, de nem mesélte el az orvos, hogy ez mit is jelent. Állt a lány elöttem értetlenül, mert az orvos semmit nem magyarázott el neki, és nem értette ezért ezt az egészet. [...] Nekem is egy csomó mindent a netröl kellett néznem, hogy egyáltalán mi micsoda, és hogy hogyan magyarázzam el egy értelmi sérültnek. Ez egy baromi nagy arculcsapás volt, hogy egy értelmi sérültnek csak ennyit mond el az orvos, hogy kromoszómabetegséged van.

É: [...] én már voltam terhes is a volt páromtól, de anyukám nem engedte, el kellett vetetni. Nehéz felnevelni egy gyermeket, de én nagyon haragudtam akkor anyukámra. Voltam 16-17 éves, az 
Farkas A. \& Jávor R.: A szociális munkás szerepe a felnőtt értelmi fogyatékossággal élő személyek...

akkori barátomtól volt. Azt mondtam neki, ha minket megszült, akkor nekem miért nem lehet. Meg hogy biztos az lett volna belöle, hogy ö neveli fel.

A párkapcsolattal rendelkező enyhe értelmi fogyatékossággal élők között többen nemi életet is élnek, ezért gyakran a védekezés gyógyszeres formáját választják. Ilyenkor a szülő vagy egy segítő elkíséri a női klienst a nőgyógyászhoz, ahol megtörténik a vizsgálat és a gyógyszerfelírás. Az ilyen helyzetekben az intézményben dolgozó szociális munkásnak segítséget kell nyújtania a kliensnek, ha a szülő nincs ott támogató személyként.

A támogatás, a fejlesztés, a tanítás és szexuális nevelés tehát mind hozzájárultak ahhoz, hogy az intim együttléteket már hosszas udvarlás és együttlét (szexuális kontaktus nélkül) elözi meg: ezek az egyének is elöször a bizalmi kapcsolatot alakítják ki. Ezt az Ámor-klubon tanultak tették lehetővé.

D: Van [szexuális kapcsolatuk], és az elején letisztáztuk, hogy mi az, amit engedünk, amiről beszélgethetünk.

P: Igen, volt már olyan, de ez titok. Mindig a gyerektémát hozza fel, pedig mondtam neki, hogy nem lehet, mert a petevezetékemmel gond van, meg gyógyszert is szedek.

\section{Értelmi fogyatékossággal élők és szociális munkások kommunikációja, magatartása}

A segítői bánásmód kialakításához is nélkülözhetetlen a jó kommunikációs készség és a gondozottakkal való kapcsolatteremtés. A gondozónak az egyén saját fejlettségi szintjén kell kapcsolatba lépnie a lakókkal, kifejezett erőfeszítéseket téve a beszéd és egyéb kommunikációs formák fejlesztésére. Erre hasznosak a kiscsoportos programok, viták, megbeszélések és interaktív technikák (Zolnai, 2001). A verbális kommunikáció korlátozott lehetősége miatt azonban a szükségletek és érzelmi állapot értelmezésében nagyobb hangsúlyt kapnak a viselkedéses megnyilvánulások, az érzelmi állapot vegetatív jelzései, a magatartás szimbolikus értelmezése, a játéktevékenység elemzése és a fantázia különböző megjelenési formái is (Stang, 2000).

Fontos, hogy jól ismerjük a kliensek értelmi képességeit, hogy mely kommunikáció és kommunikációs eszköz az, amit be tudnak fogadni. Ez hasznos lehet, amikor új ismereteket tanítunk nekik (pl. szexuális felvilágosításkor).

A gondozói magatartás és bánásmód kialakításában fontos, hogy a kliensek szükséglete, érdeke és méltósága jelenjen meg. Abból célszerü kiindulni, hogy a fogyatékossággal élő személyek is azonos vágyakkal, célokkal, érzésekkel élik meg a világot, mint ép társaik, még ha önkifejező eszközeik korlátozottabbak is. Ugyanakkor joguk van hozzá, hogy a nekik tetsző módon viselkedjenek adott helyzetekben, hiszen autonóm, független akarattal rendelkező személyek. Éppen ezért a felnőtt szereppel való felruházásuk megjelenik a megszólításukban, a velük való beszélgetésekben. Érdemes figyelnünk, hallgatnunk őket, kapcsolódni hozzájuk, hogy megismerjük személyiségüket. Döntéseiket támogatnunk kell, megtalálva az egyensúlyt a gyámkodás és a törődés között, a magukra utaltság és a korlátozás között. Döntéseik tiszteletteljes elfogadása gyakran saját erkölcsi értékeink, normáink akadályozzák meg, viszont tudnunk kell, hogy nem az a lényeg, hogy mindent helyeseljünk, amit tenni akarnak, de pusztán azért, mert döntéseiket nem fogadjuk el, ill. nem tartjuk megfelelőnek, nem akadályozhatjuk meg az esetleges hibák elkövetését sem, amennyiben ezek következményeivel a kliens tisztában van (Zolnai, 2001). Szociális munkásként segíthetjük öket abban, hogy megtanuljanak 
kifejezőbben kommunikálni, és hatékonyabban felismerni partnerük érzéseit. Ez akár egyfajta erőforrást is jelenthet önállóságuk fejlesztésében, a kapcsolataik kialakításának segítése és a szexuálpedagógiai támogatásuk mellett.

A jelen mintában enyhe és középsúlyos értelmi fogyatékossággal élők is megszólaltak, amely jellemzők kétféle gondozási igényt hordoznak magukban. „Pusztán” a gondozási feladatok körét tekintve a súlyosabb esetekben van inkább szükség komplex támogatásra, viszont ha a szerelem és a szexualitás kerül előtérbe, akkor az enyhe értelmi fogyatékossággal élőknél merül fel inkább a támogatás igénye. Ahogy már említésre került, a középsúlyos értelmi fogyatékossággal élők a szerelmet többnyire csak baráti viszonyként élik meg, a szexualitás csak ritkán jelenik meg az ő kapcsolataikban. Az enyhe értelmi fogyatékossággal élő kliensek azok, akik a szerelmi kapcsolataikat komolyan gondolják, és (általában) testileg is kiteljesednek benne. Ezért kaphat nagyobb szerepet az ő esetükben a mediációs munka, a szexuális és egyéb, hasonló jellegü felvilágosítás, a kontracepció lehetőségeinek ismertetése (edukációs jelleggel) stb. Ez természetesen nem azt jelenti, hogy a középsúlyos és súlyos értelmi fogyatékossággal élőknek nincs szükségük ezekre az információkra - a szakembernek kell a kliens lehetőségeihez mérten segítséget, támogatást és információt nyújtania, kialakítva azt a bizalommal teli környezetet és segítő kapcsolatot, amelyben ezek a szándékok, kérdések, igények megvitathatók és megvitatandók.

A Szociális Munka Etikai Kódexéböl két pontot kell kiemelni, melyek szorosan összefonódnak (nem csak) az említett csoportokkal való munkában, és amelyeket mindig és mindenkor szem előtt kell tartanunk (Szociális Szakmai Szövetség Etikai Kollégiuma, 2016):

„A szociális munkás felelősséget vállal az egyének, csoportok, családok, közösségek (továbbiakban: kliens), valamint a szervezetek, intézmények érdekeinek képviseletében és lehetőség szerinti érvényesítésében." (p. 3)

„A szociális munkás a kliens kiszolgáltatott helyzetével nem él vissza.” (p. 4)

\section{Összegzés}

Az értelmi fogyatékossággal élőket ellátó intézményekben a dolgozók nem lepődnek meg azon, hogy vannak érzelmi és szexuális igények, de még mindig nem tudják, hogyan is segítsék őket. A probléma az, hogy hiányzik az egységes intézményi gondolkodás és mentalitás, amit képviselhetnének a dolgozók a szexualitás kapcsán, és hiányoznak azok a módszerek, melyek mentén el tudnának indulni a szakemberek.

A Fogd a Kezem Alapítvány Ámor-klub-módszere egy igen jó kezdeményezés az értelmi fogyatékossággal élő kliensek egészségnevelésére. További lehetőségekkel még inkább bővíteni lehetne az edukációt, más csoportokat is bevonva:

- közös programok társszervezetekkel, ahol ismerkedhetnek a kliensek,

- közös ötletelés intézményen belül és akár intézményen kívül (más intézményekkel) is arról, hogy miről lenne érdemes beszélgetni a kliensekkel az Ámor-klubon, milyen fejlődési potenciál van magában az edukációban,

- szülői Ámor-csoport, ahol az otthoni, ill. az intézményben történő tapasztalatokat, problémákat beszélhetnék meg, támogathatnák és „taníthatnák” egymást,

- a tapasztalatokat, módszereket nyilvánossá tenni, hogy olyanokhoz is eljussanak hasonló információk, akiknek nem adatik meg a fejlődés, fejlesztés. 
Farkas A. \& Jávor R.: A szociális munkás szerepe a felnőtt értelmi fogyatékossággal élő személyek...

Más intézmények módszereiről, eszközeiről nem lelhetők fel feljegyzések. Az utóbbi években néhány intézmény már elkezdett figyelni az értelmi fogyatékossággal élők párkapcsolatainak és a szexualitás problémájára, de a módszereiket és tapasztalataikat nem osztották meg, így az Ámor-klub fontossága még nagyobb hangsúlyt kap.

Érdekesség, hogy a gyermekek szexuális nevelését a családok hatáskörébe utalja egy új törvény. A 2021. évi LXXIX. törvény (2021) szigorúan szabályozza, hogy kik és milyen feltételek mellett tarthatnak egészségfejlesztéssel kapcsolatos foglalkozást, ezzel az állam csökkenti azt a hajlandóságot, hogy az intézmények ilyen foglakozásokat tartsanak. Továbbá Magyarország Kormánya fontosnak tartja, hogy a gyermekek szexuális nevelésébe a szülökön kívül senki ne szólhasson bele, a legtöbb szülő viszont nem képes megfelelő szexuális nevelést biztosítani gyermekének, legyen ő fogyatékossággal élő vagy egészséges. Jelen tanulmány rávilágít arra, hogy a szülök gyakran tabuként kezelik a szexualitást, ezért a fiatalok először egy intézmény falai között tájékozódnak a nemiségröl.

A megoldás talán az, hogy amellett, hogy meghagyjuk a szülőknek azt a jogot, hogy ők gondoskodjanak gyermekük szexuális neveléséröl, segítjük (de legalább nem nehezítjük) a szakembereket abban, hogy egészségfejlesztéssel kapcsolatos foglalkozásokat tartsanak hasonló intézményekben.

\section{Irodalom}

Balogh, F., Balogh, L., Katona, R., Szabó, Á., \& Szabó, M. (2016). A nöiség és a nemiség kérdései értelmi fogyatékos felnőttek csoportjaiban. Az Értelmi Fogyatékossággal Élők és Segítőik Országos Érdekvédelmi Szövetsége.

Bánfalvy, Cs. (2003). Gyógypedagógiai szociológia (2. kiadás). ELTE Bárczi Gusztáv Gyógypedagógiai Kar.

Bánfalvy, Cs. (2000). Fogyatékosság és szociális hátrány. In S. Illyés (Ed.), Gyógypedagógiai alapismeretek (pp. 81-114). ELTE Bárczi Gusztáv Gyógypedagógiai Kar.

Bowlby, J. (1969). Attachment and loss: Attachment (Vol. 1). The Hogarth Press and the Institute of Psycho-Analysis.

Bowlby, J. (1973). Attachment and loss: Separation, anxiety and anger (Vol. 2). The Hogarth Press and the Institute of Psycho-Analysis.

Bowlby, J. (1980). Attachment and loss: Loss, sadness and depression (Vol. 3). The Hogarth Press and the Institute of Psycho-Analysis.

Cs. Horváth, E. (1987). Kultúra - fogyatékosság - hátrányos helyzet. Könyvtári Figyelö, 33(5), 527534.

Fábián, R., \& Simich, R. (2006). Meglévö és müködő modellprogramok, valamint az iskolai szexedukációs események értékelése. Országos Egészségfejlesztési Intézet.

Forrai, J. (2020). Fogyatékkal élők szexuális egészségpolitikája, szempontjai és problémái. Magyar Tudomány, 181(3), 314-328. https://doi.org/10.1556/2065.181.2020.3.4

G. Szabó, A. (1996). Bevezetés a gyógypedagógiába. Nemzeti Tankönyvkiadó.

Hámori, E. (2014). Kötödéselmélet régen és ma. Koncepciók, kutatás, módszerek és klinikai vonatkozások Bowlbytól napjainkig [Egyetemi jegyzet]. Pázmány Péter Katolikus Egyetem, Bölcsészet- és Társadalomtudományi Kar.

Központi Statisztikai Hivatal. (2021). Fogyatékossággal élők. KSH. https://www.ksh.hu/stadat_files/ege/hu/ege0033.html

Kvale, S. (1996). InterViews: An introduction to qualitative research interviewing. Sage.

Laki, I. (2013). A fogyatékossággal élő emberekről. Neveléstudomány: Oktatás - kutatás - innováció, 1(3), 79-85.

Magyar, A. (2018). Fejezetek az értelmifogyatékosság-kép történetéböl. Gondolat Kiadó. 
A. Farkas \& R. Jávor: The role of social workers in supporting adults with intellectual disabilities...

Mattila, J., Uusiautti, S., \& Määttä, K. (2017). How do people with intellectual disability describe the experience of falling in love? The International Journal of Emotional Education, 9(1), 71-84.

Mándoki, N. (2018). Korai kötődés, anya-gyermek interakciók és autizmus spektrum zavar. Magyar Pedagógia, 118(3), 255-278. https://doi.org/10.17670/MPed.2018.3.255

Stang, T. (2000). A viselkedészavar, mint sajátos kommunikáció. Fészek Szakmai Füzetek 1. Kézenfogva Alapítvány.

Szociális Szakmai Szövetség Etikai Kollégiuma. (2016). Szociális munka Etikai Kódexe. http://3sz.hu/sites/default/files/Etikai.pdf

Szokolszky, Á. (2004). Kutatómunka a pszichológiában. Osiris Kiadó.

Zechmeister, A. (2016). Szexuális nevelés gyakorlata értelmileg akadályozott tanulók körében. Gyermeknevelés, 4(3), 78-86. https://doi.org/10.31074/gyntf.2016.3.78.86

Zolnai, E. (2001). Felnöttek, mert felnöttek. Kézenfogva Alapítvány.

\section{Jogszabály}

2021. évi LXXIX. törvény a pedofil bünelkövetőkkel szembeni szigorúbb fellépésröl, valamint a gyermekek védelme érdekében egyes törvények módosításáról (2021). https://mkogy.jogtar.hu/jogszabaly?docid=A2100079.TV 